\title{
ARCHITEKTURA OPARTA NA WZORZE PLASTRA MIODU
}

\author{
Kinga Kimic ${ }^{凶}$
}

Wydział Budownictwa i Inżynierii Środowiska, Szkoła Główna Gospodarstwa Wiejskiego w Warszawie, Warszawa

\begin{abstract}
STRESZCZENIE
Wzór plastra miodu, wywodzący się z natury, stanowi jedną z inspiracji w kształtowaniu architektury. Charakterystyczna forma sześciokąta, dająca możliwość powielania jako modułu zarówno w „,czystej”, jak i zmodyfikowanej formie, sprzyja wdrażaniu coraz bardziej spektakularnych rozwiązań. Celem artykułu jest przegląd wybranych przykładów zastosowania wzoru plastra miodu w architekturze w odniesieniu do kształtowania jej podstawowej formy (obiektów samodzielnych i ich złożonych układów), a także detalu w różnej skali (elementach fasad budynków). Różnorodność pomysłów wynika z inwencji planistów i architektów, rozwoju innowacyjnych narzędzi projektowania, a także dostępności różnorodnych materiałów wykorzystywanych w budownictwie.
\end{abstract}

Słowa kluczowe: architektura, urbanistyka, design, plaster miodu, sześciokąt

\section{WSTĘP}

Człowiek od najdawniejszych czasów czerpie inspiracje z przyrody, a rozwój nowych technologii oraz postęp w zakresie nowoczesnych materiałów pozwalają na coraz szersze zastosowanie charakterystycznych, dających się powielać wzorów zaczerpniętych $\mathrm{z}$ natury m.in. $\mathrm{w}$ architekturze. Sprzyja to rozwojowi standaryzacji i modularności, które są jednocześnie następstwem wielokierunkowego rozwoju tej dziedziny i zobrazowaniem matematycznie wyrażanych kanonów proporcji (Tobolczyk, 2000). Jednym z charakterystycznych wzorów jest plaster miodu (Bitzer, 1997) kojarzony z konstrukcjami tworzonymi przez pszczoły i złożonymi z przylegających do siebie sześciokątnych komórek (Shaik i Shaik, 2015; Zhang, Yang, Li, Huang i Feng, 2015). Struktura ta, wykorzystywana $w$ różnych rozwiązaniach architektonicznych i urbanistyce od końca XIX wieku, pozwala obecnie na wdrażanie coraz bardziej spektakularnych rozwiązań. Stanowi inspirację do kształtowania formy danej budowli, zespołu obiektów oraz ich fragmentów. Geometria sześciokąta i sześciokątnej siatki znajduje też szerokie zastosowanie w projektowaniu generatywnym i parametrycznym (Jiang, Wang i Wallner, 2014), wpływając na tworzenie charakterystycznych form przestrzennych będących wynikiem wizualizacji matematycznych algorytmów, a także tworzenie złożonych konstrukcji obiektów architektonicznych (Jiang i in., 2014; Pottman, Eigensatz, Vaxman i Wallner, 2015). Te ostatnie wykorzystuja jako bazę heksagonalne komórki w celu maksymalizacji wytrzymałości danego układu względem najmniejszej ilości zużytego materiału budowlanego, co ma również znaczenie ekonomiczne (Nazzi, 2016) - pozwala na pełne wykorzystanie dostępnej przestrzeni obiektu i jednocześnie wpływa na obniżenie kosztów realizacji.

Celem niniejszej publikacji jest przedstawienie wybranych zastosowań wzoru plastra miodu w koncepcjach i realizacjach obiektów architektonicznych - sześciokąta jako formy stosowanej samodzielnie lub powielonej tworzącej sześciokątną siatkę. Dla 
ukazania różnorodności zastosowań uwzględniono użycie tego charakterystycznego wieloboku zarówno w „czystej”, jak i zmodyfikowanej formie w kształtowaniu planu pojedynczego obiektu lub złożonych układów obiektów, a także wybranych elementów budowli (detali architektonicznych).

\section{MATERIAt I METODY}

Artykuł, stworzony na podstawie przeglądu literatury przedmiotu, dotyczy wybranych realizacji samodzielnych obiektów architektonicznych oraz tych bęacych częścią zrealizowanych koncepcji urbanistycznych bądź pozostających jeszcze $\mathrm{w}$ fazie projektu (począwszy od końca XIX w. do współczesności), dla których opracowania inspiracją był wzór plastra miodu. Praca obejmuje rozwiązania o różnej skali i odmiennym przeznaczeniu (budynki mieszkalne - jednorodzinne i wielorodzinne, a także wielofunkcyjne obiekty użyteczności publicznej), w tym obiekty trwałe oraz tymczasowe (nietrwałe i przenośne, zaprojektowane jako struktury przewidziane na krótki czas użytkowania w danym miejscu).

Wybrane przykłady omówiono względem wykorzystania wzoru plastra miodu (sześciokąta lub siatki sześciokątnej) w odniesieniu do dwóch aspektów:

- kształtowania podstawowej formy architektury (z rozróżnieniem na obiekty samodzielne i zespoły budowli tworzące przestrzenno-funkcjonalną całość poprzez różne formy ich zestawiania i łączenia);

- zastosowania $\mathrm{w}$ detalu architektonicznym niezależnie od podstawowej formy przestrzennej budowli, jej skali i funkcji - wybranych elementów konstrukcji oraz elewacji obiektów.

\section{FORMA ARCHITEKTONICZNA - OBIEKTY SAMODZIELNE}

Wykorzystanie wzoru plastra miodu do ukształtowania formy architektury obejmuje różnorodne rozwiązania. Najprostszym jest zastosowanie sześcianu lub siatki sześciokątnej w planie samodzielnego budynku.

\section{Budynki mieszkalne i użyteczności publicznej}

Przykładem zastosowania wzoru plastra miodu w budownictwie jednorodzinnym jest sześciokątny dom mieszkalny projektu Harriet Morrison Irvin, opatento- wany w 1869 roku pod nr 94116 w Stanach Zjednoczonych (Heisner, 1981; Allaback, 2008). Stworzony na planie sześcioboku, podobnie jak jego trzy podstawowe pomieszczenia (rys. 1a), stanowił innowacyjne rozwiązanie przestrzeni mieszkalnej pozbawionej zbędnych korytarzy, co zapewniało lepszy niż w zwykłych budynkach przepływ powietrza i wydajne oświetlenie. Mimo iż żaden ze zrealizowanych obiektów nie przetrwał, konstrukcja ta - wraz z przyświecającą mu ideą działania na rzecz poprawy zdrowia użytkowników domu - wpisała się w historię rozwoju architektury opartej na wzorze plastra miodu. W końcu lat 20. XX wieku również Georges Benoit-Levy, francuski prawnik i dziennikarz, który przyczynił się do rozwoju miast-ogrodów we Francji, promował w swym kraju koncepcję Heksagonapolis - heksagonalnie rozplanowanego miasta opracowanego przez Noulana Cauchona w początku XX wieku. Zaprezentował uzupełniający go plan rozbudowanego heksagonalnego domu mieszkalnego Wilhelma Ulricha (rys. 1b; Benoit-Levy, 1929). Wśród historycznych realizacji obiektów użyteczności publicznej zaprojektowanych na planie tego charakterystycznego wzoru należy wymienić także kilkupiętrowy gmach sądu hrabstwa Nowy Jork, otwarty w 1927 roku i nadal użytkowany. Projekt opracował w 1913 roku Guy Lowell - uznany bostoński architekt. Plan sześciokątnego obiektu obejmował m.in. złożony system rozległych wnętrz usytuowanych na kilku poziomach i ułożonych wokół owalnego centralnego holu oraz charakterystyczny portyk (Werner i Clerk, 2008).

\section{Pawilony użytkowe}

Sześciokątny, regularny wzór plastra miodu jest doskonałą formą znajdującą zastosowanie w wielu konstrukcjach modułowych, które stanowią obiekty zarówno trwałe, jak i tymczasowe. Wśród przykładów z pierwszej grupy wymienić można elementy wprowadzone w parku Jubileumi w Budapeszcie, na Węgrzech w latach 60. XX wieku (Bakay, Zajacz i Szilágyi, 2016). Dwie sekwencje małych zadaszeń zostały zgrupowane po trzy i ustawione na placach wypoczynkowych (rys. 2a). Sześciokątne zwieńczenia przypominające wielkie parasolki stanowiły rozwiązania innowacyjne i na stałe wpisały się $\mathrm{w}$ program tego historycznego obiektu. Spektakularne rozwiązania $\mathrm{z}$ tego zakresu stanowią także modułowe konstrukcje nazywane 

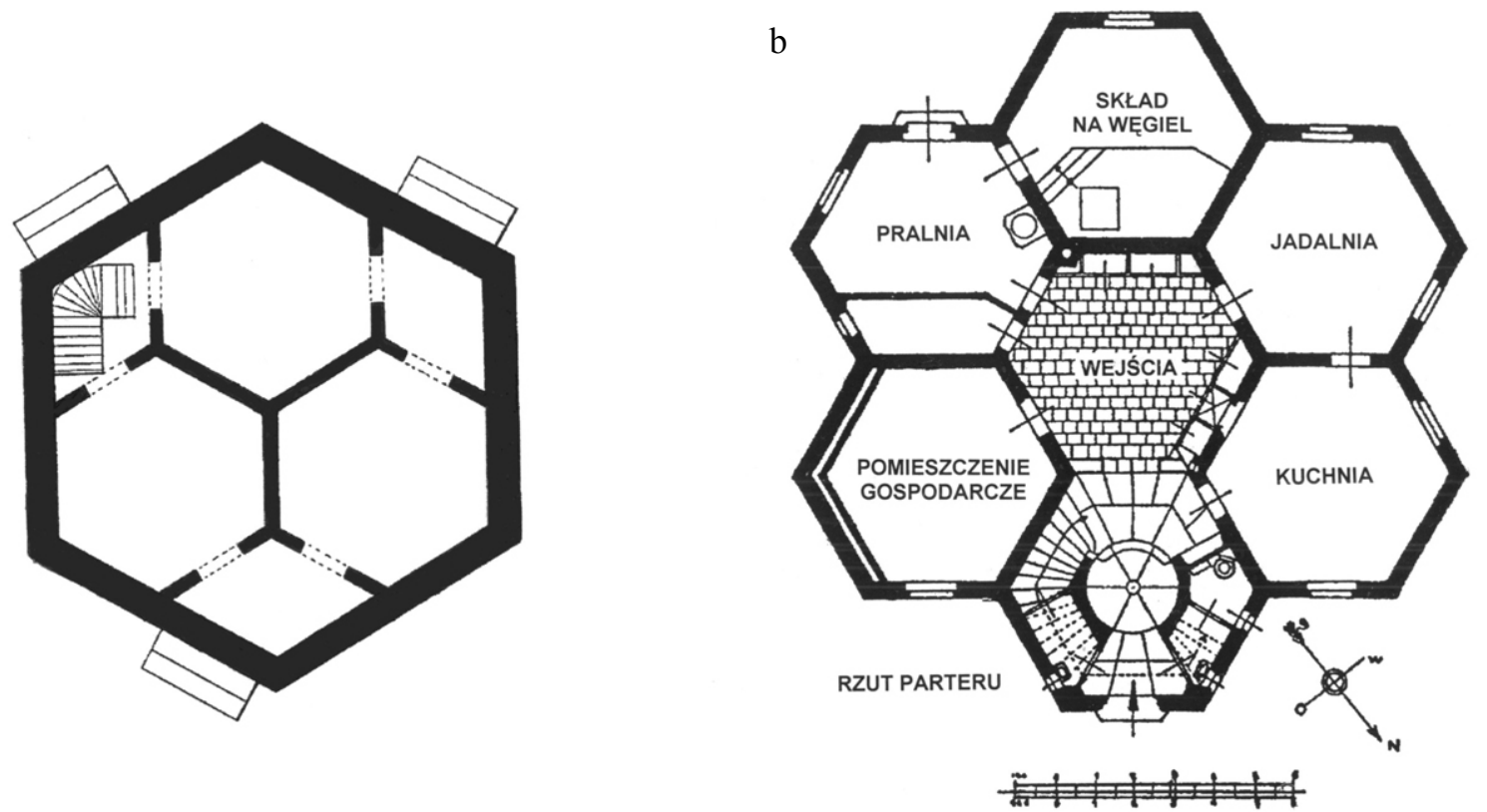

Rys. 1. Domy mieszkalne na planie sześciokąta: a - projekt z 1869 roku Harriet Morrison Irvin (oprac. autorki za: Heisner, 1981); b - projekt z ok. 1927 roku Wilhelma Ulricha (oprac. autorki za: Benoit-Levy, 1929)

Fig. 1. Hexagonal houses: a - the 1869 design by Harriet Morrison Irvin (author's preparation based on: Heisner, 1981); b - the ca. 1927 design by Wilhelm Ulrich (author's preparation based on: Benoit-Levy, 1929)

a

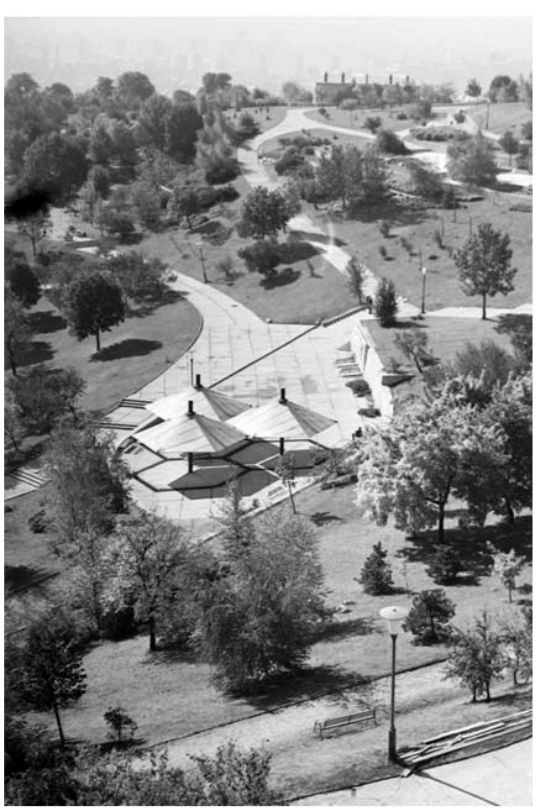

b

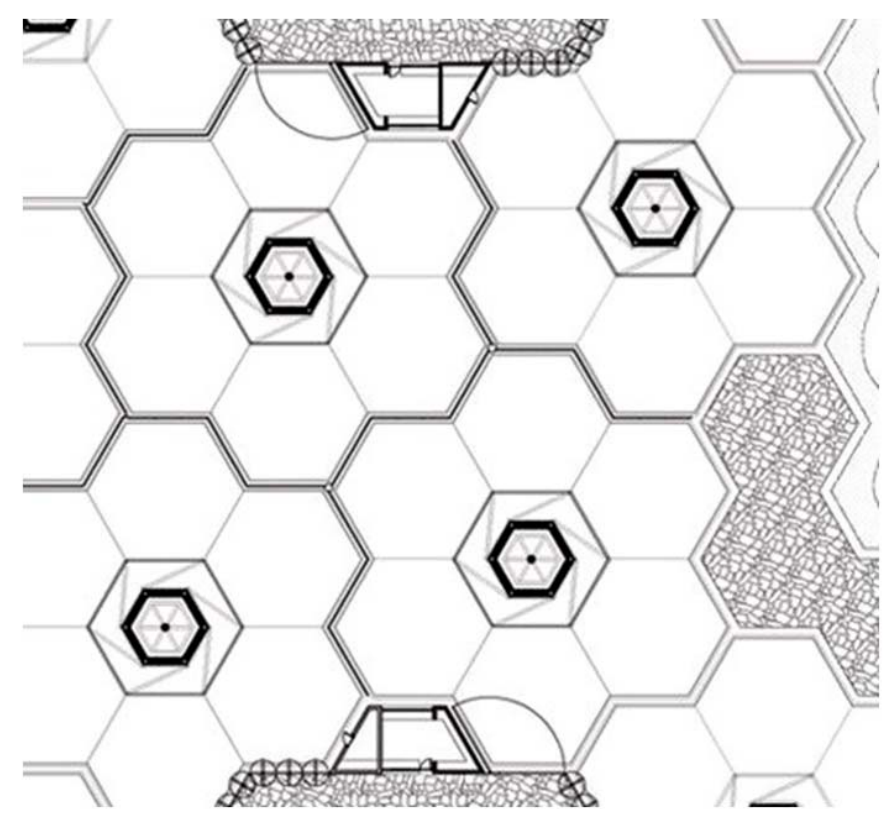

Rys. 2. Pawilony ukształtowane $\mathrm{z}$ użyciem formy sześciokąta: a - park Jubileumi, Budapeszt, Węry, stan z 1973 roku (źródło: https://upload.wikimedia.org/wikipedia/commons/f/f9/D\%C3\%A9li_lejt\%C5\%91_a_Citadella_ alatt\%2C_Jubileumi_park._Fortepan_20899.jpg); b - pojedynczy moduł zwieńczenia konstrukcji „flor-Árbol” w ogrodzie botanicznym, Medellin, Kolumbia (oprac. autorki za: Orquideorama / Plan B Architects + JPRCR Architects, 2008)

Fig. 2. Pavillions shaped using hexagonal pattern: a - Jubileumi park, Budapest, Hungary, condition in 1973 (source: https://upload.wikimedia.org/wikipedia/commons/f/f9/D\%C3\%A9li_lejt\%C5\%91_a_Citadella_alatt\%2C_Jubileumi_park._Fortepan_20899.jpg); b - a single "flor-Árbol": module used in the Botanical Garden in Medellin, Colombia (author's preparation based on: Orquideorama / Plan B Architects + JPRCR Architects, 2008) 
flor-Árbol, zbudowane w 2006 roku w ogrodzie botanicznym w Medellin, Kolumbii (rys. 2b). Składają się z sześciokątów wspartych na metalowym „pniu” o tym samym narysie i formą przypominają geometryczny kwiat. Oplecione drewnianymi listwami struktury wprowadzono dla zacienienia wybranych stref parku. Zastosowana ażurowość pozwoliła na pełne wpisanie tych elementów $\mathrm{w}$ przyrodnicze otoczenie (Orquideorama / Plan B Architects + JPRCR Architects, 2008).

Obiekty tymczasowe skonstruowane $\mathrm{z}$ zastosowaniem wzoru plastra miodu również przyjmuja różną skalę. Pawilon Treehugger, zbudowany przez studentów pod opieką architekta Holgera Hoffmanna na festiwal ogrodów BUGA 2011 w Koblencji, Niemczech, ukształtowano jako zadaszenie o modularnej strukturze sześciokątów uformowanych wokół drzewa. Uzupełniono ją wielopłaszczyznową podłogą $z$ drewnianej sklejki, a także szklaną elewacją dającą wgląd do wnętrza i świetlną wielobarwną iluminacja. Zastosowana konstrukcja umożliwia łatwy demontaż i przeniesienie obiektu w inne miejsce (Treehugger / Holger Hoffmann, One Fine Day, 2011). Tymczasową konstrukcję stanowi także instalacja Constructive Geometry Pavilion zbudowana przez studentów Wydziału Architektury Uniwersytetu w Porto, Portugalii jako efekt praktycznego zastosowania wiedzy o zasadach tworzenia kopuł geodezyjnych. Prototyp wykonano ręcznie - elementy składowe konstrukcji wycięto z falistej tektury (Grozdanic, 2012). W podobny sposób powstał obiekt Hexigloo - tymczasowy pawilon wykorzystujący strukturę komórkową plastra miodu o konstrukcji typu igloo. Zrealizowany został w ramach warsztatów projektowania parametrycznego w Bukareszcie, Rumunii w 2011 roku (Hexigloo Pavilion / Tudor Cosmatu, Irina Bogdan, Andrei Raducanu, 2011).

\section{FORMA ARCHITEKTONICZNA - UKŁADY ZABUDOWY}

\section{Zabudowa wielofunkcyjna w koncepcjach urbanistycznych}

W historii budowy miast znanych jest wiele koncepcji urbanistycznych, dla których wzór plastra miodu stanowił inspirację dla rozplanowania ich poszczególnych elementów składowych (Ben-Joseph i Gordon, 2000). W strukturach tych - obok układu komunikacji - zabudowa również powielała heksagonalny układ. Rozwiązanie, w którym sześciokątny plan ulic podkreślono formą architektury, zaproponował Bill Archer w latach 1902-1903. Poszczególne sekcje układu o narysie sześciokąta ujęto budynkiem powielającym ten kształt (długość jednego boku wynosiła $125 \mathrm{~m}$ ), tworząc wewnętrzny rozległy dziedziniec. Układ ten powielono ponownie w mniejszej skali przez sześć odrębnych obiektów liniowych tworzących wspólnie narys mniejszego sześciokąta z zachowaniem przerw pomiędzy poszczególnymi $\mathrm{z}$ nich. W ujęciu funkcjonalnym koncepcja uwzględniała zarówno obecność budynków mieszkalnych, jak i użyteczności publicznej (Müller, 1908). Podobne rozwiązania zastosował także $\mathrm{w}$ swojej koncepcji Charles R. Lamb w 1904 roku. Optował za wykorzystaniem planowania heksagonalnego dla uzyskania korzyści ekonomicznych oraz artystycznych i estetycznych przyszłych miast i dzielnic. Zaplanował organizację poszczególnych fragmentów miasta wokół wspólnych centrów, które - podkreślone układem zabudowy tworzącym charakterystyczne sześcioboczne struktury (rys. 3a) - miały zapewnić obecność określonych rodzajów usług (Lamb, 1904; Triggs, 1909). Rudolf Müller także opracował koncepcję sześciokątnych budynków (rys. 3b), które wprowadził w kwartały o heksagonalnym narysie $\mathrm{w}$ opracowanym przez niego mieście przyszłości, którego plany ideowe opublikował w 1908 roku (Müller, 1908). Koncepcje te stanowiły formę poszukiwania uniwersalnych rozwiązań służących poprawie warunków życia w miastach, a sześciokątna siatka stanowiła podstawę rozplanowania architektury opartej na tej samej formie i mieszczącej różne funkcje.

\section{Zabudowa mieszkaniowa}

Wybrane koncepcje urbanistyczne były poświęcone szczególnie organizacji terenów zabudowy jedno- lub wielorodzinnej. Przykładem kompleksowego ujęcia w zakresie wdrożenia zabudowy wielofunkcyjnej w układ sześciokątnej siatki ulic jest wcześniej wspomniana idea Hexagonopolis, którą opracował w 1927 roku Noulan Cauchon. Przekonywał on o zaletach swej koncepcji innych planistów, wskazując, iż odpowiednie zorientowanie sześciokątnej siatki ulic, do 
a

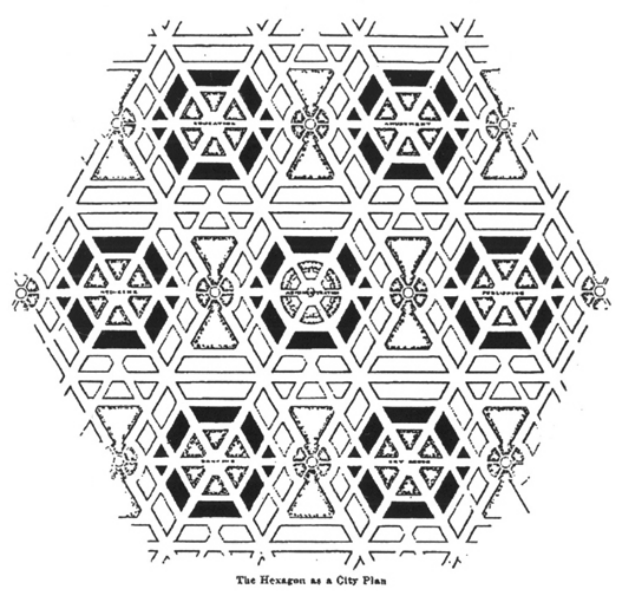

b

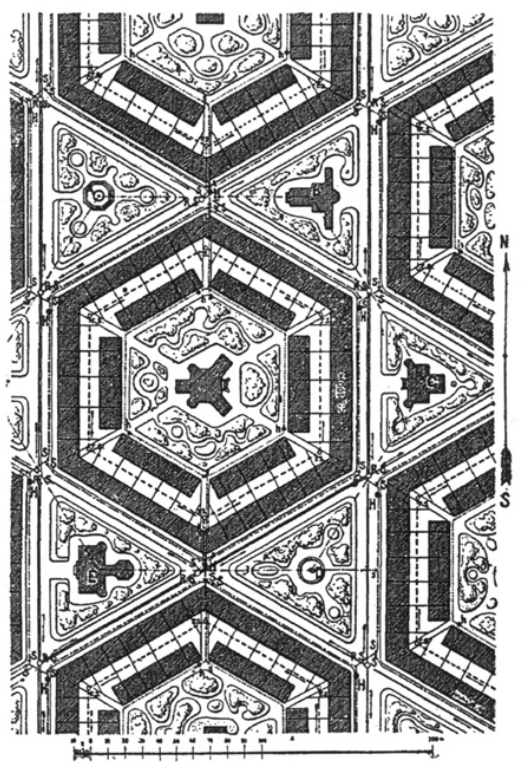

Rys. 3. Plan miasta i architektura oparte na sześciokątnej siatce: a - projekt z 1904 roku Charlesa Lamba, b - projekt z 1908 roku Rudolfa Müllera (Triggs, 1909)

Fig. 3. Hexagonal plan of the city and architecture: a - the 1904 design by Charles Lamb (1904); b - the 1908 design by Rudolf Müller (Triggs, 1909)

której przylega usytuowana w ten sam sposób zabudowa, wyeliminuje północną ekspozycję budynków mieszkalnych, co miało znaczenie $\mathrm{w}$ dobie poszukiwania rozwiązań sprzyjających poprawie zdrowia mieszkańców miast (Cauchon, 1925; 1929). Mimo to żaden z heksagonalnych obiektów według jego koncepcji nie został zbudowany. W 1928 roku Richard Barry Parker, znany ze współpracy nad koncepcjami urbanistycznymi współtworzonymi $\mathrm{z}$ Raymondem Unwinem, przedstawił własny projekt układu cul-de-sac wpisanego $\mathrm{w}$ formę sześcioboku - sześciokątną jednostkę sąsiedzką. Wdrożenie tej koncepcji było niezwykle trudne, ale zaproponował ten układ w planie miasteczka Wythenshawe pod Manchesterem (Anglia), opracowanym w latach 1927-1928, uznając go jednocześnie za doskonały przykład miasta-ogrodu nawiązujący do idei Ebenezera Howarda (Creese, 1966; Ben-Joseph i Gordon, 2000).

Współczesne realizacje wykorzystujące wzór plastra miodu do organizacji układów zabudowy dotyczą wielu znanych rozwiązań stosowanych w kształtowaniu dzielnic i wybranych obszarów miejskich połączonych z budową osiedli mieszkaniowych. W 1948 roku powstało w ten sposób osiedle gwiaździste w sztokholmskiej dzielnicy Gröndal, w Szwecji. W latach 60. XX wieku (Wiloch, 1958) rozwiązanie takie wdrożono, tworząc dzielnicę Bijlmer (skrót od Bijlmermeer) usytuowaną na przedmieściach Amsterdamu, w Holandii. Koncepcje według zasad wypracowanych na IV Międzynarodowym Kongresie Architektury Nowoczesnej (CIAM) i zapisane w Karcie Ateńskiej (1934) opracowano w zespole urbanistów Siegfrieda Nassutha. Wielorodzinną zabudowę mieszkaniową stanowiło 31 wysokich galeriowców o wydłużonych formach, w których kolejne moduły zostały załamane pod odpowiednim kątem, tworząc narys plastra miodu (rys. 4a). Wprowadzono jednocześnie ścisły podział funkcji mieszkalnej, komunikacyjnej i rekreacyjnej (Orchowska, 2015). Wykorzystanie planu opartego na sześciokątnej siatce miało zapewnić każdemu mieszkaniu dostęp do światła słonecznego, a cały kompleks określano mianem raju otoczonego bujną roślinnością z nowoczesnymi apartamentowcami dostępnymi dla klasy średniej. W podobny sposób ukształtowano osiedle Zaspa w Gdańsku, którego projekt powstał pod kierunkiem Romana Hordyńskiego w 1973 roku. 
a

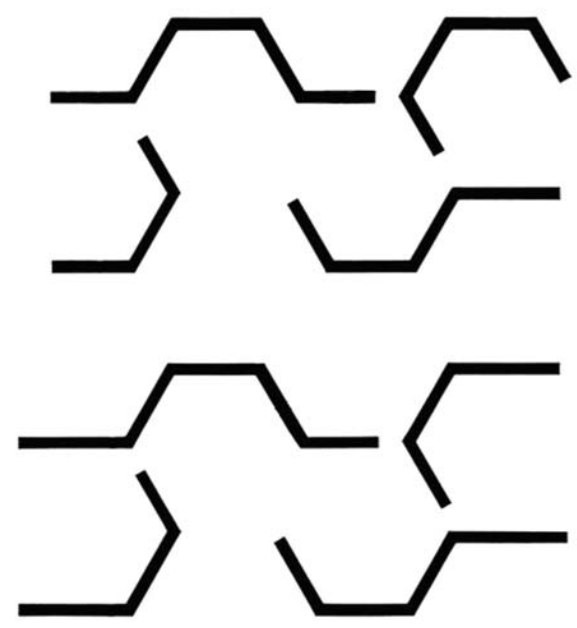

b

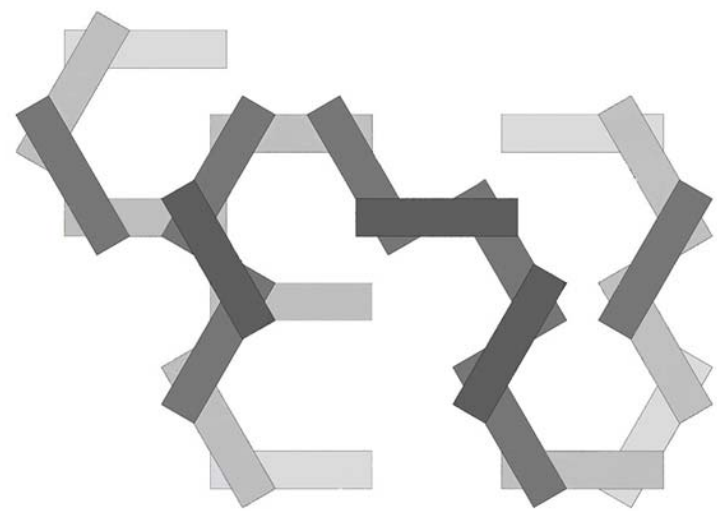

Rys. 4. Zabudowa mieszkaniowa wielorodzinna opracowana na planie sześciokąta: a - koncepcja z lat 60 . XX wieku, Bijlmeer, Holandia (oprac. autorki za: Ahh, 2019); b - projekt z lat 2007-2013, „Interlace”, Singapur (oprac. autorki za: OMA, 2018)

Fig. 4. Multi-family blocks built on a hexagonal grid plan: a - the 1960s concept, Bijlmeer, the Netherlands (author's preparation based on: Ahh, 2019); b - the 2007-2013 project, „The Interlace”, Singapore (author's preparation based on: OMA, 2018)

Osiedle to było realizowane do lat 80 . XX wieku (Rembarz, 2008; Daniluk i Wasielewski, 2012). Jego charakterystyczny heksagonalny plan podkreślony został przez układ pojedynczych liniowych wielokondygnacyjnych budynków mieszkalnych ustawionych w różnej długości ciąi, tworzących wyróżniającą się strukturę w skali miasta. Dodatkowo budynki te różnią się wysokością i tworzą charakterystyczne schodkowe układy.

Jedną z najnowszych realizacji wykorzystujących wzór plastra miodu jest projekt „The Interlace” wdrożony w latach 2007-2013 w Singapurze według projektu Olego Scheerena i pracowni projektowej Office for Metropolitan Architecture (Frearson, 2015). Prezentuje on innowacyjny sposób kształtowania wielopoziomowej architektury. W układ włączono 31 budynków mieszkalnych - każdy o sześciu kondygnacjach i identycznej długości. Poszczególne moduły zostały ułożone do wysokości 24 pięter na czterech poziomach, jeden na drugim, z przesunięciem oraz pozostawieniem wolnych przestrzeni, tworząc sześciokątny układ zorganizowany wokół ośmiu dziedzińców (rys. 4b). Pozwoliło to na utrzymanie prywatność poszczególnych mieszkań przy jednoczesnym stworzeniu przestrzeni wspólnych z dużym udziałem zieleni, a także otwarcie widoków na otoczenie (OMA, 2018).

Innowacyjną propozycją, stworzoną $\mathrm{w}$ myśl idei rozwoju zrównoważonego, są projekty opracowane przez francuskiego architekta Vincenta Callebauta przewidziane na 2050 rok dla Paryża. W koncepcji bioorganicznych inteligentnych wież mieszkalnych uwzględnił on formę opartą na wzorze plastra miodu, dodatkowo zintegrowana z zielenią i tworząca przez to doskonałą przestrzeń życiową dla mieszkańców. Każdy budynek stanowi złożony, przyjazny dla środowiska przyrodniczego system przepełniony technicznymi rozwiązaniami oczyszczającymi powietrze, wspomagającymi retencję wody i produkcję energii z odnawialnych źródeł (Giermann, 2015).

\section{ELEMENTY ARCHITEKTONICZNE}

Wzór plastra miodu stanowi inspirację dla kształtowania nie tylko planu i ogólnego układu budowli. Znajduje również zastosowanie $\mathrm{w}$ wybranych elementach, w tym fragmentach konstrukcji uwidocznionych $\mathrm{w}$ różnym zakresie, a szczególnie w detalach architektonicznych, niezależnie od wiodącej formy 
przestrzennej danego obiektu. Zarówno regularny sześciokąt inicjujący określony porządek wynikający $\mathrm{z}$ jego geometrii, jak i liczne modyfikacje tej figury dają możliwość swobodnego jej powielania dla uzyskania nieskończenie rozległych struktur tworzonych przez ściśle ze sobą połączone pojedyncze elementy. Struktury te nadają się do zastosowania w budynkach o znacznej kubaturze, w tym w obiektach o dużej wysokości, ze względu na ich lekkość i wytrzymałość (John, John i Skarka, 2016). Dzięki temu wykorzystywane są w tworzeniu elewacji obiektów - zarówno konstrukcji tarasów i balkonów o formach modułowych, jak i okładzin tworzących charakterystyczny rysunek wyróżniający dany budynek spośród innych. Uwzględniając dodatkowe rozwiązania o różnym stopniu ażurowości i różnej skali, a także możliwość łączenia ze sobą odmiennych materiałów, znacząco poszerza się liczba potencjalnych kombinacji w zakresie kształtowania płaskich lub niezwykle fantazyjnych struktur.

\section{Fragmenty budowli - elewacje}

Wzór plastra miodu wkomponowano w budynek Saint John's Abbey - klasztor benedyktynów w Collegeville Township w stanie Minnesota, Stanach Zjednoczonych. Projekt Marcela Breuera realizowany w latach 1958-1961 objął wykonanie północnej elewacji obiektu jako ażurowej konstrukcji wykorzystującej heksagonalny rysunek, przez co stanowi ona jeden z najbardziej wyróżniających się fragmentów budowli - unikalną ścianą witraży złożoną z 430 kolorowych sześciokątów (Young, 2014).

Spektakularny przykład realizacji z XXI wieku stanowi National Aquatics Center Water Cube w Pekinie. Obiekt zbudowany na igrzyska olimpijskie w 2008 roku zyskał elewację opartą na wzorze plastra miodu, która poprzez wypełnienie wolnych przestrzeni transparentnymi wypukłymi panelami nawiązuje dodatkowo do kropli wody. Zastosowano w niej innowacje inżynieryjne - transparentne „bąbelki” są doskonałym izolatorem termicznym, a jednocześnie około $20 \%$ pozyskanej energii słonecznej służy do ogrzewania basenów i wnętrza. Pomyślano też o ponownym użyciu i recyklingu $80 \%$ wody zebranej ze zlewni dachów (Arup, 2008). Fasada prostopadłościennych brył dwóch budynków - niższego o wysokości $88 \mathrm{~m}$ oraz wyższego sięgającego $358 \mathrm{~m}$ - składających się na kompleks Sinosteel International Plaza w Tianjing, Chinach, również zaprojektowana została $\mathrm{z}$ heksagonalnych paneli. Układ ten mieści różnej wielkości sześciokątne okna, które zestawione ze sobą tworzą charakterystyczna strukture plastra miodu. Fasada pełni funkcję ozdobną i stanowi jednocześnie szkielet konstrukcji budowli, dzięki któremu jest on bardziej efektywny energetycznie - okna rozlokowano względem kierunków przepływu powietrza i penetracji promieni słonecznych, co zmniejsza utratę ciepła zimą i chłodzi obiekt latem (dll, 2008). Heksagonalne elementy zastosowano w konstrukcji wieżowca One Delisle w Toronto, Kanadzie. Tworzą go ośmiokondygnacyjne woluminy ułożone w stos, $\mathrm{z}$ których każdy ma kształt zniekształconego sześcioboku. Zastosowano tu rozwiązania proekologiczne - dach każdej $\mathrm{z}$ oszklonych konstrukcji wspomagających system zacienienia budynku tworzy dodatkową powierzchnię przeznaczoną dla roślinności (Gibson, 2018). Podobne elementy uwzględniono w konstrukcji i elewacji wielorodzinnego domu Albany Marina Residences na Wyspach Bahama. Fasada o strukturze plastra miodu tworzy południową ścianę, w której sześciokąty są oprawą balkonów z prywatnymi basenami ujętymi szklanymi balustradami (Frearson, 2014).

\section{Okładziny zewnętrzne budynków}

Elewacje budynków nawiązujące formą do plastra miodu mogą być wykonane $\mathrm{z}$ różnych materiałów, a także elementów pojedynczych zestawianych ze sobą lub wycinanych w większej strukturze. Rozwiązaniem stosującym samodzielne elementy wkomponowane w regularna fasadę jest budynek firmy Estar Móveis w São Paulo, Brazylii. Sporej wielkości pełne panele stalowe pomalowane na odcienie brązu i szarości, a także elementy ażurowe pokryły niemal całą elewację, pozostawiając jedynie nieregularne przerwy w miejscach okien. Układ ten chroni wnętrza przed tropikalnym słońcem i przyczynił się jednocześnie do podwyższenia rozpoznawalności budynku (Estar Móveis / SuperLimão Studio, 2013). Zupełnie inny charakter nadano elewacji obiektu biurowego Campus Netzwerk w miejscowości Töging am Inn, w Niemczech. Oprogramowanie parametryczne wykorzystano do opracowania wzoru plastra miodu, który wycięto 
laserem w aluminiowej powierzchni okrywającej jedną z długich fasad budynku. Wielkość otworów wynika $\mathrm{z}$ konieczności doświetlenia wnętrz - w strefach zacienionych drzewami są one większe, a w silnie nasłonecznionych zostały maksymalnie zmniejszone (Griffiths, 2014). Zróżnicowanie to pozwoliło uniknąć wrażenia monotonii.

\section{PODSUMOWANIE}

Przedstawione przykłady wykorzystania wzoru plastra miodu w architekturze dotyczą rozwiązań stosowanych $\mathrm{w}$ różnym zakresie i różnej skali. W każdym z przypadków stanowią formę poszukiwania rozwiązań innowacyjnych opartych na interpretacji tego wzoru w „czystej” formie sześciokąta lub jego autorskiej modyfikacji, wykorzystywanych do nadania obiektom i ich elementom unikalnego charakteru wyróżniającego je spośród pozostałych realizacji. Sa jednocześnie świadectwem poszukiwania rozwiązań inspirowanych naturą, które znalazły przełożenie na powstające w kolejnych dekadach nowe obiekty i ich zespoły.

Wzrost zainteresowania wzorem plastra miodu, zwłaszcza w końcu XX i w XXI wieku, poparty jest coraz bardziej różnorodnymi koncepcjami, wynika nie tylko z inwencji architektów, ale także rozwoju innowacyjnych narzędzi projektowania i technologii umożliwiających wdrożenie skomplikowanych konstrukcji oraz kształtowania złożonych brył budynków. Uwarunkowany jest również dostępnością nowoczesnych materiałów pozwalających na uzyskanie unikalnych efektów wizualnych w kształtowaniu detalu architektonicznego, w tym form i wzorów stosowanych dla podniesienia atrakcyjności i poprawy funkcjonowania elewacji obiektów.

\section{PIŚMIENNICTWO}

Ahh (2019). Bijlmer monument, Amsterdam (1994-1998). Pobrane z lokalizacji: https://www.ahh.nl/index.php/ en/projects2/13-cultuur/116-bijlmer-monument-amsterdam [dostęp dd-mm-2018].

Allaback, S. (2008). The First American Women Architects. Urbana and Chicago: University of Illinois.

Arup (2008). National Aquatics Center (Water Cube), Beijing. A form inspired by the natural formation of soap bubbles. Pobrano z lokalizacji: https://www.arup. com/projects/chinese-national-aquatics-center [dostęp 15.09.2018].

Bakay, E., Zajacz, V. i Szilágyi, K. (2016). Késő modern kertépítészeti örökségünk - Az 50 éves Jubileiumi park. 4d Tájépitészeti És Kertmüvészeti Folyóirat, 42, 2-17.

Ben-Joseph, E. i Gordon, D. (2000). Hexagonal Planning in Theory and Practice. Journal of Urban Design, 5 (3), 237-265.

Benoit-Levy, G. (1929). L'habitation hexagonal. La Technique du Traveaux, 8, 417-421.

Bitzer, T. (1997). Honeycomb technology: Materials, Design, Manufacturing, Applications and Testing. London: Chapman \& Hall.

Cauchon, N. (1925). Hexagonal blocks for residential districts. The American City, 17, 145-146.

Cauchon, N. (1929). Hexagonal planning and housing. W Proceedings of the Tenth National Conference on Housing. January 1929 Philadelphia. New York: National Housing Associsation.

Creese, W. L. (1966). The Search for New Environment: The Garden City Before and After. New Haven: Yale University Press.

Daniluk, J. i Wasielewski, J. (2012). Dolny Wrzeszcz i Zaspa. Seria: Gdańskie dzielnice. Gdańsk: Wydawnictwo Oskar.

dll (2008). Sinosteel International Plaza od MAD. Pobrano $\mathrm{z}$ lokalizacji: http://www.bryla.pl/bryla/1,85298, 5720079,Sinosteel_International_Plaza_od_MAD.html [dostęp 16.09.2018].

Estar Móveis / SuperLimão Studio (2013). Archdaily, 25 grudnia. Pobrano z lokalizacji: https://www.archdaily. com/460873/estar-moveis-superlimao-studio [dostęp 04.12.2018].

Frearson, A. (2014). BIG designs honeycomb housing block for the Bahamas. Dezeen, 27 stycznia. Pobrano z lokalizacji: https://www.dezeen.com/2014/01/27/bigbjark-ingels-honeycomb-housing-bahamas/ [dostęp 16.09.2018].

Frearson, A. (2015). Ole Scheeren's "vertical village" named World Building of the Year 2015. Dezeen, 6 listopada. Pobrano z lokalizacji: https://www.dezeen. com/2015/11/06/ole-scheeren-the-interlace-vertical-village-singapore-building-of-the-year-2015-world-architecture-festival-2015/ [dostęp 18.11.2018].

Gibson, E. (2018). Studio Gang proposes honeycomb-like One Delisle skyscraper for Toronto. Dezzen, 6 lipca. Pobrano z lokalizacji: https://www.dezeen. com/2018/07/06/one-delisle-studio-gang-honeycombskyscraper-toronto-canada/ [dostęp 14.11.2018]. 
Giermann, H. (2015). Vincent Callebaut's 2050 Vision of Paris as a "Smart City". Archdaily, 8 stycznia. Pobrano z lokalizacji: https://www.archdaily.com/585254/vincentcallebaut-s-2050-parisian-vision-of-a-smart-city [dostęp 21.11.2018].

Griffiths, A. (2014). Honeycomb perforations speckle facade of Campus Netzwerk office by Format Elf Architekten. Dezeen, 29 sierpnia. Pobrano z lokalizacji: https:/www.dezeen.com/2014/08/29/campus-netzwerkoffice-format-elf-architekten-perforated-aluminium/ [dostęp 14.11.2018].

Grozdanic, L. (2012). Constructive Geometry Pavilion Investigates Dome Structures Through Mass-Customization. eVolo, 13 sierpnia. Pobrano z lokalizacji: http://www. evolo.us/constructive-geometry-pavilion-investigatesdome-structures-through-mass-customization/ [dostęp 11.12.2018].

Heisner, B. (1981). Harriet Morrison Irwin's Hexagonal House: An Invention to Improve Domestic Dwellings. The North Carolina Historical Review, 58 (2), 105-124.

Hexigloo Pavilion / Tudor Cosmatu, Irina Bogdan, Andrei Raducanu (2011). ArchDaily, 1 lipca. Pobrano z lokalizacji: https://www.archdaily.com/146764/hexigloopavilion-tudor-cosmatu-irina-bogdan-andrei-radacanu [dostęp 11.12.2018].

Jiang, C., Wang, J. i Wallner, J. (2014). Freeform Honeycomb Structures. Computer Graphics Forum, 33 (5), 185-194. doi: 10.1111/cgf.12444

John, M., John, A. i Skarka, W. (2016). Analiza wytrzymałości struktury typu plaster miodu w elementach podporowych. Mechanik, 4, 316-317. doi: 10.17814/mechanik. 2016.4.43

Lamb, Ch. (1904). City plan. The Craftsman, 6, 3-13.

Müller, W. (1908). The city of the future: hexagonal building concept for a new division. W Österreichische Wochenschrift für den öffentlichen Baudienst, 15. Pobrano z lokalizacji: http://urbanplanning.library.cornell.edu/ DOCS/muller.htm [dostęp 12.12.2018].

Nazzi, F. (2016). The hexagonal shape of the honeycomb cells depends on the construction behavior of bees. Scientific Reports, 6, \#28341. doi: 10.1038/srep28341

Office for Metropolitan Architecture [OMA] (2018). The Interlace. Pobrano z lokalizacji: https://oma.eu/projects/ the-interlace [dostęp 18.11.2018].
Orchowska, A. (2015). Współczesne reinterpretacje w przestrzeni miejskiej. Środowisko Mieszkaniowe, 15, 124-131 .

Orquideorama / Plan B Architects + JPRCR Architects (2008). ArchDaily, 17 maja. Pobrano z lokalizacji: https://www.archdaily.com/832/orquideorama-plan-barchitects-jprcr-architects [dostęp 11.09.2018].

Pottman, H., Eigensatz, M., Vaxman, A. i Wallner, J. (2015). Architectural geometry. Computers \& Graphics, 47, 145-164. doi: 10.1016/j.cag.2014.11.002

Rembarz, G. (2008). „Serce dzielnicy” w stanie embrionalnego rozwoju-śródmieście reurbanizowanego wielkiego osiedla w polskim mieście metropolitalnym. Czasopismo Techniczne. Architektura, 4-A, 105-113.

Shaik, N. i Shaik, A. (2015). Design and Analysis of Honey Comb Structures with Different Cases. International Journal of Ecology and Development Research, 3 (4), 144-156.

Tobolczyk, M. (2000). Narodziny architektury. Warszawa: Wydawnictwo Naukowe PWN.

Treehugger / Holger Hoffmann, One Fine Day (2011). ArchDaily, 5 maja. Pobrano z lokalizacji: https://www. archdaily.com/132639/treehugger-holger-hoffmannone-fine-day/ [dostęp 14.09.2018].

Triggs, H. I. (1909). Town Planning Past Present and Possible. London: Methuen \& Co.

Werner, J. F. i Clerk, C. (2008). The New York County Courthouse. A Brief Architectural/Design History 60 Centre Street. Pobrano z lokalizacji: https://www.nycourts.gov/ courts/1jd/supctmanh/Courthouse\%20History 102012. pdf [dostęp 11.12.2018].

Wiloch, J. (1958). Szwecja. Rozwój układu osiedla mieszkaniowego. Architektura, 12, 483.

Young, V. M. (2014). Saint John's Abbey Church: Marcel Breuer and the Creation of a Modern Sacred Space. Minneapolis: University of Minnesota Press.

Zhang, Q., Yang, X., Li, P., Huang, G. i Feng, S. (2015). Bioinspired engineering of honeycomb structure - Using nature to inspire human innovation. Progress in Materials Science, 74, 332-400. doi: 10.1016/ j.pmatsci.2015.05.001 


\section{ARCHITECTURE BASED ON A HONEYCOMB PATTERN}

\section{ABSTRACT}

The honeycomb pattern, comes from nature, is one of the inspiration used by architects in their work. The characteristic form of the hexagon, possible to be duplicated as a module in both "pure" and modified form, favours the implementation of more and more spectacular solutions in architecture. The aim of the article is an overview of selected examples of the honeycomb pattern applied in architecture in relation to shaping its basic form (single objects and their complex systems), as well as used in architectonic details at various scales (elements of building facades). The variety of ideas is resulted from the inventiveness of planners and architects, the development of innovative design tools, and the availability of various materials used in construction.

Key words: architecture, urban planning, design, honeycomb, hexagon 